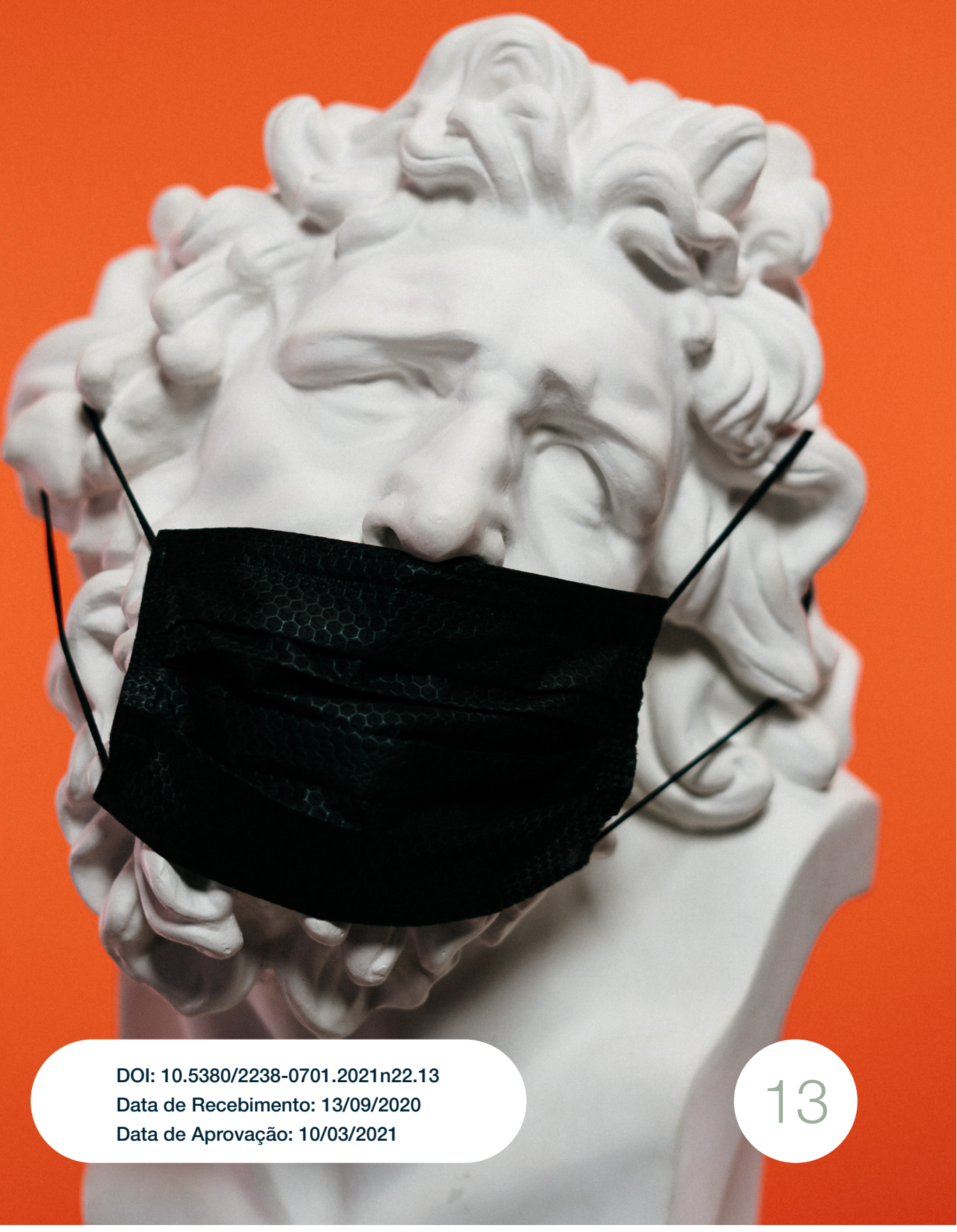


Sobre vírus, bactérias e animais: o bestiário simbólico de filmes sobre pandemias 


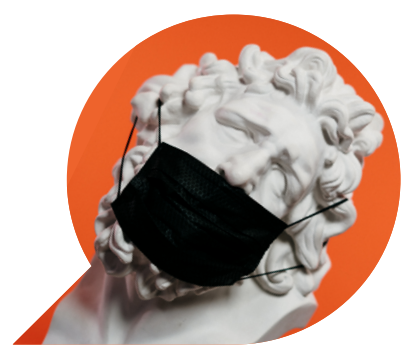

\title{
Sobre vírus, bactérias e animais: o bestiário simbólico de filmes sobre pandemias
}

\author{
Sobre virus, bacterias y animales: el bestiario simbólico \\ de películas sobre pandemias
}

\section{About viruses, bacterium and animals: the symbolic bestiary in pandemic movies}

DANILO FANTINEL ${ }^{1}$

Resumo: A pandemia de COVID-19 reativou medos ancestrais decorrentes de doenças e da morte. Porém, elaboramos conteúdos do imaginário que atenuam essas angústias. Esses elementos imaginados instigam formas de pensar e de agir, estimulando também obras culturais, artísticas e midiáticas. Neste artigo, estudamos dez filmes para evidenciar o bestiário inspirador de títulos sobre surtos, epidemias e pandemias. Observamos também a imagem simbólica do inimigo invisível ligada a agentes patogênicos infecciosos e mortíferos. Para isso, recorremos aos Estudos do Imaginário, sobretudo a noções oferecidas por Gillbert Durand.

Palavras-chave: Imaginário; imagem; bestiário; cinema; pandemia.

1 Mestre e doutorando em Comunicação e Informação pelo PPGCOM da Universidade Federal do Rio Grande do Sul (UFRGS) com estágio doutoral na Université Jean Moulin Lyon 3 com bolsa de estudos da Coordenação de Aperfeiçoamento de Pessoal de Nível Superior - Brasil (CAPES) no âmbito do Programa Capes-Prlnt. O presente trabalho foi realizado com apoio da Capes - Código de Financiamento 001. 


\begin{abstract}
The coronavirus disease pandemic has amplified ancestral fears of contagion and death. However, we create symbolic images to mitigate this anguish. These imaginary elements instigate thinking and behavior as well as culture, arts and media. This paper aims to highlight the symbolic bestiary that inspires ten pandemic movies. This study also points out the symbolic image of the invisible enemy attached to pathogens responsible for infections and deaths. In order to do that, we turned to the Imaginary Studies, especially to Gilbert Durand's work.
\end{abstract}

Keywords: Imaginary; image; bestiary; cinema; pandemic.

Resumen: La pandemia de COVID- 19 reactivó los miedos ancestrales por la enfermidad y la muerte. Sin embargo, nuestra imaginación simbólica crea contenidos imaginarios que mitigan estas ansiedades. Estos elementos imaginados instigam formas de pensar y actuar, inspirando también obras culturales, artísticas y mediáticas como las películas de cine. En este artículo, estudiamos diez películas de largometrages para destacar el bestiario inspirador sobre brotes, epidemias y pandemias, observando también la imagen simbólica del enemigo invisible vinculado a agentes patógenos responsables de infecciones y muertes. Para ello recorrimos a los Estudos del Imaginario, especialmente a las nociones que ofrece Gilbert Durand.

Palabras-clave: Imaginario; imagen; bestiario; cinema; pandemia.

\title{
Imaginação simbólica e atenuação das angústias
}

A pandemia do vírus SARS-CoV-2, causador da doença COVID-19, alterou hábitos pessoais e atingiu estruturas sociais, políticas e econômicas em diversos países. O grande número de infectados e de mortos 2atualizou nossos medos do tempo opressor, das doenças incapacitantes e da morte. Porém, com imaginação simbólica (DURAND, 2000) elaboramos conteúdos imaginários que atenuam nossas angústias e

2 Conforme a Organização Mundial da Saúde (OMS) havia 163.869.893 casos confirmados de COVID-19 e 3.398.302 mortes causadas pelo SARS-CoV-2 no mundo até 19 de maio de 2021. Fonte: https://covid19.who.int/. 
inspiram nossa cultura. Esses elementos imaginados instigam formas de pensar e de agir, animando também obras culturais, artísticas e midiáticas, como filmes. Igualmente dedicadas ao pensamento sobre a condição humana, as narrativas cinematográficas também equacionam nossas aflições frente ao perigo microbiológico, oferecendo representações que tanto reagem a crises sanitárias registradas no mundo quanto antecipam cenários futuros devastadores.

Neste artigo, estudamos dez filmes sobre surtos, epidemias e pandemias que apresentam animais como vetores de vírus, bactérias ou parasitas: Pânico nas ruas (1950), O Sétimo Selo (1957), Epidemia (1995), Os 12 macacos (1995), Extermínio (2002), Eu sou a lenda (2007), REC (2007), Contágio (2011), The Bay (2012) e A gripe (2013). Buscamos evidenciar o bestiário simbólico que influencia esses títulos cinematográficos para compreender quais sentidos movem as tramas. O estudo demonstrou que imagens simbólicas de certas espécies têm maior presença neste bestiário, como aquelas ligadas a aves, morcego, rato, macaco, cão e leão. Entretanto, nesses longas-metragens sobre doenças e infecções causadas por agentes patogênicos microscópicos, o medo de um inimigo invisível é onipresente. Como veremos, essa ameaça não visível está miticamente alinhada à morte.

Resultante da experiência dos sujeitos em seus percursos pelo mundo, o imaginário antropológico delineado por Gillbert Durand (2012) é um dinâmico sistema de arquétipos, imagens simbólicas, simbolismos, mitos e metáforas que integra gerações transculturalmente. Esses conteúdos do imaginário são antropológicos porque seus sentidos se formam na vivência do sujeito imaginante, de modo que a semântica desses elementos não é arbitrária, mas motivada pela experimentação do mundo pelo indivíduo. Assim, é natural que o bestiário integre o imaginário. Para Durand (2012, p. 70), as simbolizações envolvendo imagens de animais são tão importantes que qualquer estudo sobre imaginário antropológico deve incluir um segmento dedicado às imagens e sentidos figurados vinculados à fauna, pois "[...] o bestiário parece (...) solidamente instalado na língua, na mentalidade coletiva e na fantasia individual”.

Nesta pesquisa, buscamos compreender como se constitui o simbolismo animal deste imaginário do pandêmico estimulador dos filmes estudados. Não se trata, então, de um escrutínio sobre o amplo bestiário, relativo a toda a fauna simbolizada pela imaginação humana, mas de observações sobre a simbólica movida por certos animais que 
acaba por inspirar os longas-metragens deste corpus. O presente texto se conecta a outro estudo ${ }^{3}$ sobre o imaginário do pandêmico vivificante deste segmento cinematográfico.

\section{Tipologia da imagem e espectro imaginário}

A pesquisa em cinema pela heurística dos Estudos do Imaginário solicita a diferenciação entre duas noções de imagem. Nesta tradição, a imagem é entendida como simbólica, ou seja, símbolo de sentido vivido. Resultante da confluência entre a essência pulsional do indivíduo e as coerções oriundas do meio histórico-social no qual ele vive (DURAND, 2012), a imagem simbólica acontece na experiência e faz sentido no instante. Ela não representa um sentido. Ela é o próprio sentido. Trata-se de uma imagem imaterial elaborada pelo sujeito, pelo corpo, mais apreciada por sensação do que por visão. Durand (2000), Gaston Bachelard (1990) e Mircea Eliade (2002, 2016) concordam que sua presença se faz sentir pela sensibilidade imaginante. Portanto, a imagem simbólica é livre de face representativa, visualidade ou materialidade - ainda que, posteriormente, venha a motivar representações culturais, artísticas e midiáticas.

As imagens cinematográficas têm outras características. Próximas das imagens técnicas definidas por Flusser (2011), elas são dependentes de suporte material, produzidas e reproduzidas com o auxílio de aparelhos mediante as subjetividades e intencionalidades de seus realizadores. Essas imagens audiovisuais em movimento são próprias à codificação e decodificação, representação e significação. Jacques Aumont $(2011,2013)$ sublinha a capacidade de impressão de realidade das imagens visuais do cinema segundo soluções estético-narrativas suscetíveis a uma análise fílmica que possa segmentar e examinar os códigos de sua linguagem audiovisual. Integradas à mediosfera ${ }^{4}$ (CONTRERA, 2017), imagens técnicas, visuais e midiáticas permitem a mediação entre o sujeito e o mundo.

3 O artigo Caos, escatologia e morte: sintomas de um imaginário do pandêmico no cinema (FANTINEL, 2021 integra o dossiê Imaginários contagiantes: Fantasia, horror e ficção científica na era da COVID-19, publicado pela revista Zanzalá.

4 Conforme Malena Contrera, a mediosfera é a dimensão do imaginário mediático dotada de imagens, textos e significações que cresce em paralelo à noosfera, dimensão da mente/espírito concebida por Edgar Morin. 
Na potência do imaginário irradiador de sentidos sobre a cultura, as artes e a mídia, imagens simbólicas estimulam imagens técnicas tanto quanto outros elementos audiovisuais do filme. Desse modo, em leituras simbólicas ou em mitocríticas fílmicas ${ }^{5}$, buscamos a interpretação de obras cinematográficas tendo em vista o encontro entre dimensões da imagem ${ }^{6}$ que são diferentes entre si, mas complementares.

A tipologia da imagem na pesquisa em cinema pela perspectiva dos Estudos do Imaginário convida a observações mais detalhadas sobre esse espectro teórico.Em seu estudo sobre o imaginário antropológico, no qual observou criticamente mitos, lendas, folclore e obras literárias, Durand (2012)dividiu esse sistema dinâmico de conteúdos simbólicos em dois grandes regimes. Um é marcado por grande ansiedade decorrente da passagem do tempo e da ameaça da morte. O outro, pelo eufemismo desse sentimento.

No Regime Diurno, há uma oposição interna entre imagens, simbolismos e valorizações semânticas decorrentes da opressão temporal mortífera. De um lado, polarizam-se conteúdos imaginários vinculados a terríveis experiências decorrentes dessa angústia. Imagens e sentidos de valorização negativa quanto ao tempo e à morte constelam nos simbolismos teriomórfico (que responde à aflição provocada pela temporalidade e pela mortalidade segundo nossas experiências com os animais, constituindo assim um rico bestiário), nictomórfico (que reage ao mesmo tormento, mas alinhando-se à obscuridade da noite profunda, à escuridão sinistra e às trevas infernais) e catamórfico (no qual as imagens da queda elaboram a agonia da consumação humana pelo tempo originando imagens descendentes, de precipitação e decadência; o decaimento simbólico nos lembra sobre nossa condição humana, terrestre e mortal, introduzindo na vertigem do tempo o aspecto catastrófico

\footnotetext{
5 Mitocrítica fílmica: percursos para a pesquisa e a interpretação de filmes pela heurística do imaginário (FANTINEL, 2021) é capítulo do livro Pontes para o audiovisual: teorias e métodos, editado pelo Programa de Pós-Graduação em Cinema e Audiovisual da Universidade Federal Fluminense (PPGCine-UFF) em parceria com a Nau Editora. 6 Para aprofundar a compreensão sobre aproximações e distanciamentos entre as imagens técnicas e as imagens simbólicas recomendamos nosso artigo Diferenças imagéticas: considerações sobre a técnica e o símbolo no contexto comunicacional (BARROS; DE CARLI; FANTINEL, 2016) .
} 
e punitivo da queda seja para Ícaro7 ${ }^{7}$ seja para Adão ${ }^{8}$; cair equivale simbolicamente a morrer). Porém, na coincidência opositora que equaliza o símbolo imaginário, esse mesmo Regime Diurno também converge imagens, símbolos e sentidos de luta contra o tempo e a morte, destacando assim três outros simbolismos complementares: o ascensional (dinamizado pelo esquema da elevação e por imagens de ascensão, verticalização e voo contra a queda simbólica), o espetacular (reúne o arquétipo da luz e as imagens simbólicas dele decorrentes, como luz suprema, arrebatadora, brilho ofuscante - em oposição às trevas e aos símbolos tenebrosos) e o diairético (marcado pela virilidade heroica e pelas imagens e sentidos de valentia, potência, distinção e separação cortante entre bem e mal, luz e trevas; se o movimento ascensional se dá contra a queda e se a luz brilha contra a escuridão, o herói imaginário se une a ambos e ergue-se fulgurante contra um abismo de trevas).

Por outro lado, o Regime Noturno de imagens tende ao eufemismo, harmonizando o sujeito com o tempo e a morte. Surge um agrupamento imaginário mais feminino, uterino e acolhedor, composto por simbolismos de inversão e intimidade apaziguantes, acolhedores. Neste regime de imagens, a queda transforma-se em descida lenta, controlada e indolor; as trevas desesperadoras se resolvem em noite tranquila; o tempo nefasto e mortal torna-se ciclo astrobiológico (re)produtivo e regenerador; enquanto a morte terrível vira um belo descanso eterno.

\footnotetext{
7 Na mitologia grega, Ícaro fugiu do labirinto do Minotauro e da llha de Creta voando com asas feitas de penas coladas com cera por seu engenhoso pai, Dédalo. Mas o jovem não seguiu os conselhos do sábio, que o advertiu para não voar nem muito baixo, evitando a umidade das águas do mar, nem muito alto, pois o calor do sol derreteria a cera que prendia penas e plumas. Porém, seduzido pelo voo livre que o aproximou do céu, do sol e dos deuses, Ícaro elevou-se cada vez mais até perder seu aparato alado. Caiu no mar, afogando-se nas profundezas. A queda de ĺcaro não deixa de ser moral, fruto de ego inflado.

8 Na narrativa mítica de Gênesis, Deus adverte que Adão e Eva não devem comer do fruto da árvore do bem e do mal, alocada no centro do Jardim do Éden. Entretanto, a ordem é transgredida por Eva e depois por Adão após a mulher ser convencida pela serpente questionadora. A soberba e a desobediência de ambos causam a ruptura na relação harmônica entre Deus e o primeiro casal, instaurando assim o pecado original. Como resultado, Adão e Eva são expulsos do paraíso, tornando-se mortais e levando à queda da humanidade. Também como castigo, a mulher é condenada a ter seu desejo voltado para o homem, a sofrer na gravidez e ter dores ao dar à luz. Já o homem é condenado a trabalhar a terra para dela tirar seu sustento. O pecado original seria remediado somente pela igreja católica mediante o batismo.
} 


\section{O inimigo invisível}

Nos filmes estudados, o medo de um inimigo invisível é constante. O temor frente a um agente patogênico microscópico, imperceptível e potencialmente mortal se propaga em contextos diegéticos que refletem o aumento do número de infectados e de mortos; a sobrecarga do sistema de saúde; as dificuldades sociais, científicas, político-administrativas e econômicas; bem como o descontrole da crise que leva à falência social, interdições, evacuações, lei marcial e à coerção por militares, polícias, milícias, seitas fanáticas ou terroristas.

Nos longas, como na vida, esse invisível é ameaçador por ser provavelmente letal e estar possivelmente em todo lugar. Microbiológico, da ordem da partícula, esse perigo não se vê, não se deixa ver. E, ainda que inobservável pelo olho humano, sua ameaça provoca temor crescente, como se a morte estivesse à espreita.

Na mitologia grega, o invisível está ligado ao divino, ao sagrado, ao sobrenatural, ao mundo dos mortos e à ocultação pelo esquecer. O invisível liga-se a Hades, o cruel e implacável filho de Crono e Réia, irmão de Zeus e senhor do mundo subterrâneo. O nome Hades também designa seu próprio reino de trevas, território dos mortos. Na luta contra os Titãs, os Ciclopes deram a Hades um capacete que o tornava invisível, porém a invisibilidade é intrínseca a esse deus também pela função mítica de seus domínios. No mito, as imagens do Hades giram em torno da desolação, sendo, conforme Jean-Pierre Vernant (1990, p. 146), uma "[...] morada gélida, reino das sombras, mundo do esquecimento". Seria mesmo um mundo infernal habitado por uma "[...] multidão anônima de defuntos esquecidos" (VERNANT, 1990, p. 84).

A dualidade complementar dos símbolos permite equacionar valorizações entre Zeus e Hades, vida e morte, ser e não-ser, visível e invisível. Conforme Vernant (1990), se o céu etéreo e iluminado pertence a Zeus, a sombra nevoenta é de Hades. Brandão (1986, p. 176) sublinha que, quando lançados ao Hades por Zeus, os homens se dissipam no anonimato da morte. Ser levado às trevas do Hades significa deixar o mundo dos homens para habitar um mundo de sombras em que corpo já não há, onde a alma se desvanece e a existência torna-se inviável, invisível. Ora, se junto ao "Hades rei dos mortos" (Hesíodo, 1995, p. 114) a morte se traduz em esquecimento, então nem mesmo a visibilidade 
será lembrada. Por isso, Vernant (1990, p. 394) destaca que, nessa tradição, "[...] a oposição fundamental é a do visível e a do invisível", ou da vida e da morte, pois "[...] a morte, Hades, é precisamente o invisível".

Nos filmes sobre pandemia, o medo da ameaça mortal invisível é constante, pois o perigo microscópico, viral ou bacteriano, é silencioso, furtivo, imperceptível ao olho humano. Porém, do ponto de vista imaginário, o medo da ameaça invisível pode ser simbolicamente motivado pelo temor mítico da morte, do apagamento da existência dos mortais nas sombras do Hades subterrâneo.

\section{O bestiário simbólico}

Assim como ocorre em epidemias reais, filmes também apontam espécies da fauna como vetores de patógenos. No caso do SARS-CoV-2, a cadeia de transmissão entre animais e humanos ainda é estudada. A OMS (World Health Organization, 2020) informou que a origem do vírus está nos morcegos, porém investiga outros elos nessa corrente, como os pangolins que eram vendidos vivos no mercado de Wuhan, na China, local de registro do primeiro surto da pandemia ${ }^{9}$.

De forma geral, vírus estão estáveis na natureza, sem causar doenças em seus hospedeiros. Porém, quando espécies vivem muito próximas, a transmissão entre elas pode chegar ao humano. O filme Contágio representa esse percurso ao mostrar como uma norte-americana é contaminada com o vírus fictício MEV-1, em Hong Kong, ao apertar a mão de um chef de cozinha que não se higienizou após preparar carne de leitão. $\mathrm{O}$ animal havia ingerido uma banana mastigada por um morcego infectado. No filme, a personagem se torna a paciente zero, disseminando o vírus entre os participantes de um jantar. A partir deste evento, o vírus se espalha rapidamente em um mundo conectado pelo trânsito aéreo internacional.

9 Os primeiros casos do novo coronavírus foram registrados em dezembro de 2019, mas pesquisas indicam que o vírus já circulava pelo mundo antes deste período (UFSC, 2020). Em fevereiro de 2021, Peter Ben Embarek, chefe da missão internacional da OMS que investiga a origem do surto que levou à pandemia, informou que "[...] não há provas de que o vírus estava circulando em Wuhan antes de dezembro de 2019", o que coloca em dúvida se a cidade chinesa foi mesmo o epicentro pandêmico (PANCINI, 2021). 
A função dos animais na disseminação de germes inscreve-os entre agentes de perigo em pandemias, ampliando naturalmente nossos medos de espécies da fauna associadas à possibilidade de doença ou morte. E, como visto, nossa angústia primordial decorrente dos processos destrutivos do tempo e da morte também foi simbolizada segundo as experiências negativas de humanos com bichos. Assim, animais podem estimular tanto um medo real quanto um temor imaginado.

\section{Animais alados}

Ao verificar a herança mítica, lendária, folclórica e poética de antigas culturas, Durand concluiu que, no bestiário integrado ao imaginário antropológico, os sentidos ligados à vida, à liberdade, ao celestial ou ao divino constelam com a imagem simbólica de animais alados. Porém, seres com asas também lançam sombras sobre a imaginação humana.

Como visto à página 04 , os simbolismos ascensionais e espetaculares convergem no Regime Diurno do imaginário, pois as imagens e a semântica dos movimentos verticais e do voo constelam com o simbolismo inspirado pelo arquétipo da luz. Voar é elevar-se, descolar-se do solo (sujo) para lançar-se ao ar (puro) estando simbolicamente perto dos deuses solares - o que leva às simbolizações positivas das aves no imaginário antropológico. Se voos míticos buscam a liberdade, o sol e o céu divinos, como o voar audacioso e trágico de ĺcaro, os voos dos animais alados também costumam simbolizar a total autonomia. Seu movimento aéreo notável se integra à pureza do mundo natural e do ar, de modo que, em ambos os casos, voar traduz a libertação de uma condição terrena ou de uma situação terrestre.

Em seu estudo sobre a imaginação material ligada aos quatro elementos da cosmologia grega ${ }^{10}$, Bachelard (1990) observou a produção de poetas, escritores, artistas visuais e naturalistas para compreender o simbolismo aéreo e o movimento no ar. O autor faz uma investigação pteropsicológica das artes e das ciências naturais para descrever as imagens e sentidos que sobrevoam certa poética das asas. Atento às interações simbólicas e poéticas entre os pássaros, o ar e o céu,

10 Terra, fogo, água e ar 
Bachelard sublinha que o voo constitui a imagem do dinamismo perfeito. A pureza do ar, a clareza da luz e o esplendor do céu demandam poeticamente a liberdade das asas e dos seres alados, de modo "[...] que o céu seja um mundo de asas" (BACHELARD, 1990, p. 82).

No entanto, a dualidade do símbolo imaginário também concede valorizações negativas às asas, aos movimentos aéreos e ao canto das aves. Os pássaros da noite, seus voos rasantes, emboscadas e sons misteriosos inspiram medos, sentidos obscuros e distúrbios psíquicos. Ao estudar doenças da mente em contextos simbólicos, culturais e cognitivos relacionados ao sobrenatural, José Geraldo Marques (2010) propõe transversalidades entre etnopsiquiatria, etnozoologia e etnoecologia $^{11}$. Assim, descreve transtornos que acometem populações tradicionais do Norte e Nordeste brasileiros e que resultam da escuta do canto de pássaros. O trabalho aponta sentidos simbólicos nefastos em experiências patológicas de sujeitos com vocalizações de aves.

Marques (2010, p. 03) diz que a escuta do canto de certas espécies "[...] poderia vir a deflagrar adoecimentos etnopsiquiatricamente diagnosticados, cuja sintomatologia inclui distúrbios emocionais e psíquicos transdisciplinarmente identificáveis". O autor cita as vocalizações do "acauã" (Herpethoteres cachinnans ${ }^{12}$ ) como causadoras de semidemência e como presságio de desgraças e prenúncio de morte; do "ticuã" (Piaya cayana ${ }^{13}$ ), causador de melancolia, tristeza ou depressão; do inambu-anhagá, que rouba a razão ou a alma; e da matintaperera (Tapera naevia ${ }^{14}$ ), que dá corpo à alma penada ou voz a espíritos.

Se no imaginário certas aves simbolizam alguns de nossos maiores medos (entristecer, enlouquecer, morrer), é natural que filmes sobre surtos virais, doenças e pandemias sejam simbolicamente motivados por valorizações semânticas negativas emitidas por pássaros. Em A gripe, o vírus H5N1, causador da gripe aviária, torna-se mortal. O patógeno chega à Coréia do Sul incubado em imigrantes ilegais transportados em um contêiner. A doença respiratória causa hemorragia, erupções cutâneas e morte em poucas horas. A epidemia se espalha sem controle provocando dois mil mortos por hora. Ao fim do dia, um estádio de

\footnotetext{
11 Segundo Marques (2010, p. 02 e 03), trata-se do estudo dos pensamentos, conhecimentos, crenças, sentimentos e comportamentos que intermedeiam as interações entre as populações humanas e os ecossistemas. 12 Ouça o acauã em: https://youtu.be/f8DD6biSvbk.

13 Ouça o ticuã em: https://youtu.be/Zp6A-3JaGwc.

14 Ouça a matintaperera em: https://youtu.be/JvkoVX1hE2A.
} 
futebol torna-se um gigantesco crematório destinado a mortos e a doentes irrecuperáveis. A cena dantesca é uma das muitas soluções histriônicas do filme. Ainda assim, a motivação simbólica do inimigo viral invisível alinhado à vetorização aviária da doença mortal energizam o imaginário pandêmico que move o longa.

Aves também emitem valorizações negativas e sentidos de morte sobre The Bay. No filme, parasitas mutantes atacam peixes e crustáceos nas águas de Chesapeake Bay (EUA), poluídas por dejetos da indústria de frangos. O consumo de animais infectados e de água contaminada desencadeia uma grave doença entre a população. Adaptado aos humanos, o parasita isópodo oriundo das aves (na diegese) causa infecções, comendo a carne deteriorada de dentro para fora do corpo até eclodir em feridas. Dezenas de infectados superlotam o hospital local em poucas horas. O prefeito nega problemas sanitários e as autoridades federais se omitem, provocando o acúmulo de mortos nas ruas. O surto é combatido com aplicação de cloro na baía. Já o escândalo sobre doentes e mortos é abafado em acordo judicial entre o município e a indústria de frango. De fato, a produção de frangos não aparece no filme. No entanto, a simbolização negativa das aves se coloca como dínamo irradiador de sentidos nefastos sobre o filme, sendo mesmo a origem dos males no longa.

Figura 1 - Cenas do filme Contágio (2011, fotos de divulgação).

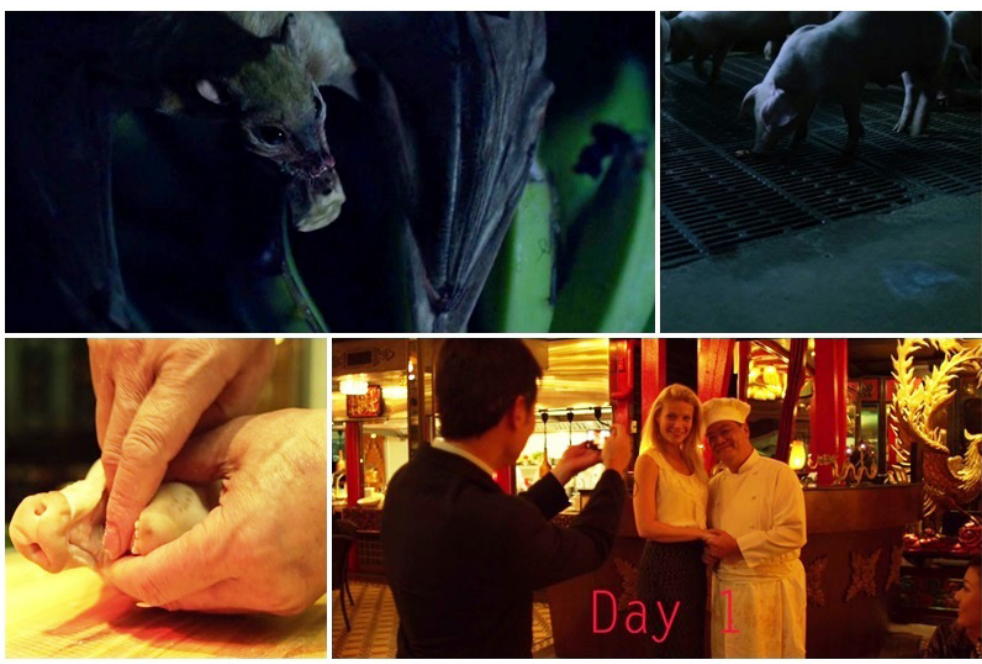


Assim como o céu não é domínio exclusivo dos pássaros, o bestiário simbólico inspirador dos filmes sobre pandemia também não é ambiente restrito às aves. Outros seres alados se movem nesse espaço etéreo, especialmente os morcegos - espécie apontada como hospedeira natural do SARS-CoV-2. A imagem simbólica do morcego tem um semantismo polarizado. Na China, é símbolo de felicidade e lucro. Para os maias, simbolizava divindade. Para índios norte-americanos, marca a intuição e os sonhos. Porém, na Idade Média europeia o simbolismo do morcego passou a convergir valorizações negativas vinculadas à noite, aos pesadelos, à escuridão cavernosa, às trevas infernais, a seres malignos e à morte ${ }^{15}$. Entretanto, apesar das cavidades rochosas da Terra que acoIhem o morcego fazerem constelar nele sentidos positivos de repouso e fertilidade (visto que esse animal vive protegido no ventre da Grande Mãe arquetípica, a Terra, de onde renasce todas as noites para se alimentar e polinizar a natureza), é mesmo o sentido tenebroso da imagem do morcego que prevalece no imaginário do pandêmico motivador de filmes do corpus. Em Contágio, o morcego é artífice da morte, pois parte dele o vírus causador de uma devastadora pandemia. Bachelard (1990) comenta que a produção poética alinha o morcego aos voos mudos, soturnos, sombrios. Esses voos noturnos que cortam as trevas e lançam mistérios sobre a imaginação humanas se opõem aos voos dos pássaros diurnos, energizados pela pureza solar, celestial e divina. $\mathrm{O}$ autor lembra que $\mathrm{O}$ simbolismo obscuro do morcego ajudou a incrustar na cultura seres míticos e fantásticos como o grifo, o dragão e a quimera.

\section{Animais terrestres}

Durand também observou que, no bestiário ligado ao imaginário, os sentidos opressivos e funestos são muito comuns entre seres ctônicos. Répteis, equinos, ursos, felinos e canídeos, entre outras espécies terrestres, podem ${ }^{16}$ ser simbolicamente associados à queda da humanidade, à morte, às trevas infernais, ao ocaso e também aos movimentos cósmicos ligados à passagem do tempo.

15 Huizinga (2010, p. 230) descreve que uma das mais comuns representações da morte no medievo era a de uma "[...] megera com patas de morcego".

16 A reversibilidade do símbolo garante valorizações tanto negativas quanto positivas às imagens simbólicas decorrentes de nossas experiências com animais. Essas segundas não serão abordadas neste trecho do artigo. 
Em Pânico nas ruas, longa policial cujo enredo se desenrola em contexto de crise sanitária, a peste pneumônica, bacteriana, é transmitida aos humanos por pulgas de ratos que chegam aos Estados Unidos em um navio mercante. Pulgas de ratos também contaminam humanos com a bactéria causadora da peste bubônica em O Sétimo Selo, cuja trama situa-se na Idade Média europeia. A Grande Peste, ou Peste Negra, provocou pelo menos 25 milhões de vítimas no continente de 1347 a1351 17 . Em ambos os filmes, são os ratos e não as pulgas que movem um semantismo terrífico alinhado à doença, à morte e ao tempo que finda. No imaginário, os ratos adquirem valorizações positivas e negativas em diversas culturas. Porém, sendo um ser ctônico, especialmente ligado ao subterrâneo, associam-se ao rato os sentidos simbólicos do submundo, das trevas, do além-mundo, além da morte. Furtivo, resistente aos piores ambientes e alimentos, o rato acumulou valorizações negativas em sua imagem simbólica, despertando assim metáforas quanto a condutas humanas reprováveis como deslealdade, desonra, dissimulação e ardileza.

Imagens e sentidos negativos ligados aos primatas também atuam no simbolismo animal de filmes sobre pandemia. Curiosamente, em culturas do Extremo Oriente a imagem do símio converge inteligência, sorte, empatia e felicidade, mas se degrada até tornar-se metáfora para pessoas desagradáveis, traiçoeiras ou trapaceiras. No Antigo Egito e no Sul da Ásia, o macaco tornou-se sagrado, intocável. No hinduísmo, motiva o deus Hanuman, símbolo de mente livre, devoção e autocontrole. Porém, o pensamento moralista cristão associou simbolicamente a agilidade, a travessura, a confiança e a lascívia do macaco à vaidade, insolência, dissimulação e devassidão dos homens. Valorizações negativas também energizam simbolicamente personagens macacos em filmes estudados neste artigo, irradiando sentidos infames sobre as tramas.

17 O número de mortos varia conforme a fonte. Neste artigo, seguimos as informações oferecidas pelos historiadores Vera Machline (2011) e Voltaire Schilling (2020). 
Figura 2 - Cenas do filme Epidemia (1995, foto de divulgação).
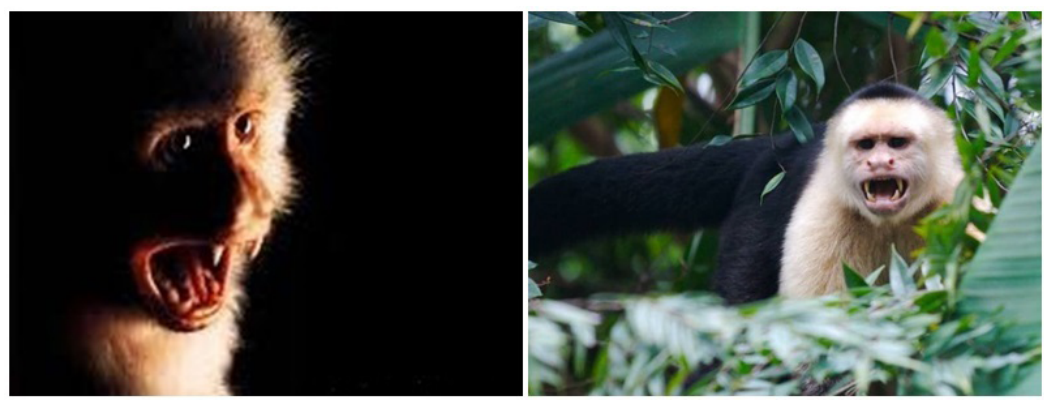

Em Epidemia, macacos infectados traficados da África para os Estados Unidos atacam humanos transmitindo a eles o vírus fictício motaba, inspirado no ebola. Um surto sobrecarrega o sistema hospitalar de uma cidade com doentes e mortos. As autoridades declaram não apenas o perigo do inimigo microbiológico invisível, mas também do macaco portador do vírus, que passa a ser caçado por especialistas. O filme destaca close-ups de um primata agitado, grunhindo alto e exibindo dentes afiados - atributos que, como veremos adiante, desempenham papel significativo no imaginário.

Curiosamente, em Os 12 macacos apenas suspeita-se que símios disseminaram um vírus mortífero pelo planeta, resultando na morte de cinco bilhões de pessoas em 1997. Mesmo assim, primatas emitem sentidos pérfidos ao longo da trama pelo menos até que se descobre a real origem do contágio: uma ação terrorista. Entretanto, macacos não aparecem nas cenas do filme, exceto em pichações ou em stickers colados pelas ruas de Nova York. Por outro lado, diversas espécies de animais surgem representadas no filme, não como vetores do microrganismo letal, mas sim enquanto novos habitantes da cidade abandonada - algo semelhante ao registrado no início da pandemia de COVID-1918. Na obra de Terry Gilliam, baratas, aranhas, pombos, um urso e um leão passeiam por uma Nova York fantasma. Voltaremos ao felino a seguir.

18 Radio France Internationale (BECHARA, 2020), BBC News Brasil (2020) e CNN (LANZONI, Will; ALMOND, Kyle, 2020) registraram a presença de animais em áreas urbanas durante a pandemia de SARS-CoV-2. 
Figura 3 - Cena do filme Extermínio (2002, fotos de divulgação).

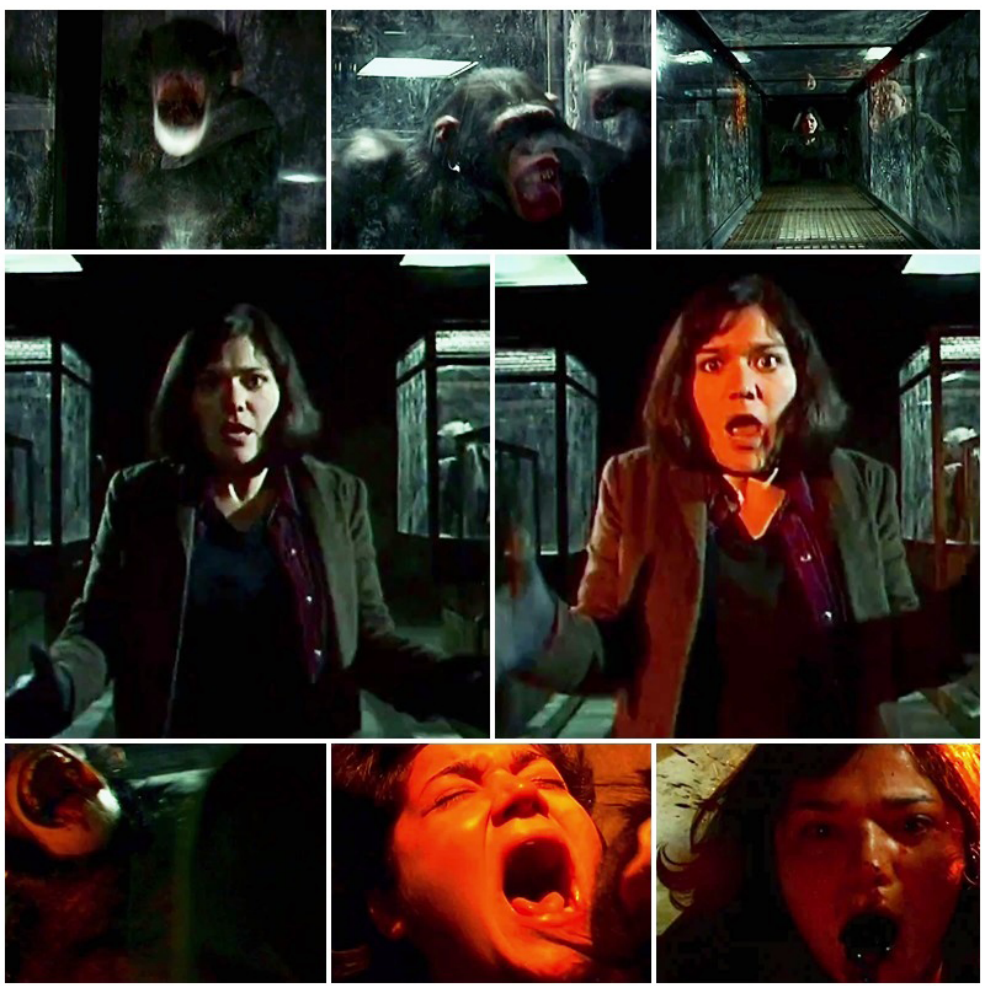

Já em Extermínio os sentidos negativos emitidos pela imagem simbólica do macaco voltam a atuar sobre a trama. Aqui, chimpanzés de laboratório são infectados com uma incontrolável cepa do vírus da raiva, transmitindo-a imediatamente a ativistas dos direitos dos animais que são mordidos quando abrem uma jaula. O patógeno atua biopsiquicamente, tornando o hospedeiro um zumbi raivoso. Após 28 dias, o Reino Unido está devastado e isolado, e sua população, morta ou evacuada. A cena do contágio da paciente zero é violenta e ruidosa. Mostra um sangrento ataque a dentadas e aos gritos. Na trama, a função do primata é ser vetor do vírus. Porém, na perspectiva do imaginário, o sadismo simbólico do macaco é o fator que leva à degradação do humano, então jogado na condição de um não-ser e nas trevas de uma nãomorte pelo símio ardil. 
Entre os muitos temas negativos inspirados pelo simbolismo animal, Durand (2012, p. 85) se refere à imagem da boca dentada, armada com presas pontiagudas, como a entrada de uma "[...] goela terrível, sádica e devastadora" que emite um "[...] grito animal (...) inumano", como que saído das cavernas e das sombras. Ao estudar mitos, lendas e literatura, Durand (2012, p. 89) conclui que as mandíbulas do animal mutilador estão ligadas tanto à imagem do mal devorador da carne quanto ao mal devorador da alma, sendo essa bocarra dentada uma "[...] boca do inferno", ou uma "[...] cratera de mil dentes, boca aberta do abismo". A mordedura consome o espírito humano nas trevas, levando à invisibilidade mítica no Hades ${ }^{19}$. Na imagem simbólica da boca dentada letal, o grito animal é o "[...] aspecto ruidoso da teriomorfia"20" (DURAND, 2012, p. 79). De fato, nos filmes que protagonizam macacos como vetores de microrganismos mortíferos, não faltam mandíbulas ameaçadoras, presas afiadas, mordidas, gritos apavorantes e grunhidos bestiais.

Bocas dentadas também marcam carne e espírito em Eu sou a lenda. Na terceira versão cinematográfica do romance de Richard Matheson ${ }^{21}$, uma epidemia de krippin virus ${ }^{22}$ tem início após a mutação do vírus do sarampo empregado em uma pesquisa para a cura do câncer. A alteração genética garantiu ao vírus 90\% de letalidade. Assim, a pandemia que começou com o adoecimento de pessoas em tratamento de câncer resultou na morte de 5,4 bilhões de pessoas. Apenas 1,2 milhão de indivíduos se mostra imune, enquanto 588 milhões se infectam. Esses doentes que não morreram acabaram mutando, tornando-se criaturas vampirescas mortíferas, sensíveis à luz. À noite, elas caçam sobreviventes imunes como Robert Neville, cientista obcecado por vacina ou cura que se vê como o último homem vivo em uma Nova York destruída.

\footnotetext{
19 O jornalismo também recorre a imagens simbólicas para metaforizar os achados das ciências na compreensão do mundo e do cosmos. Nuño Dominguez (2020) afirma que "[...] buracos negros são corpos tão densos que sua força de gravidade atrai qualquer coisa que caia em suas bocarras, incluindo a luz, por isso são invisíveis". De fato, essa boca cósmica de trevas inescapáveis engole e desintegra tudo.

20 Como visto à página 04, o simbolismo teriomórfico refere-se às imagens motivadas por animais.

21 Mortos que matam (1964), de Ubaldo Ragona, e A última esperança da Terra (1971), de Boris Sagal, foram as primeiras versões do livro de Matheson.

22 Krippin assemelha-se a creeping, "arrepiante" em inglês.
} 
Figura 4 - Cena de Eu sou a lenda (2007, foto de divulgação).
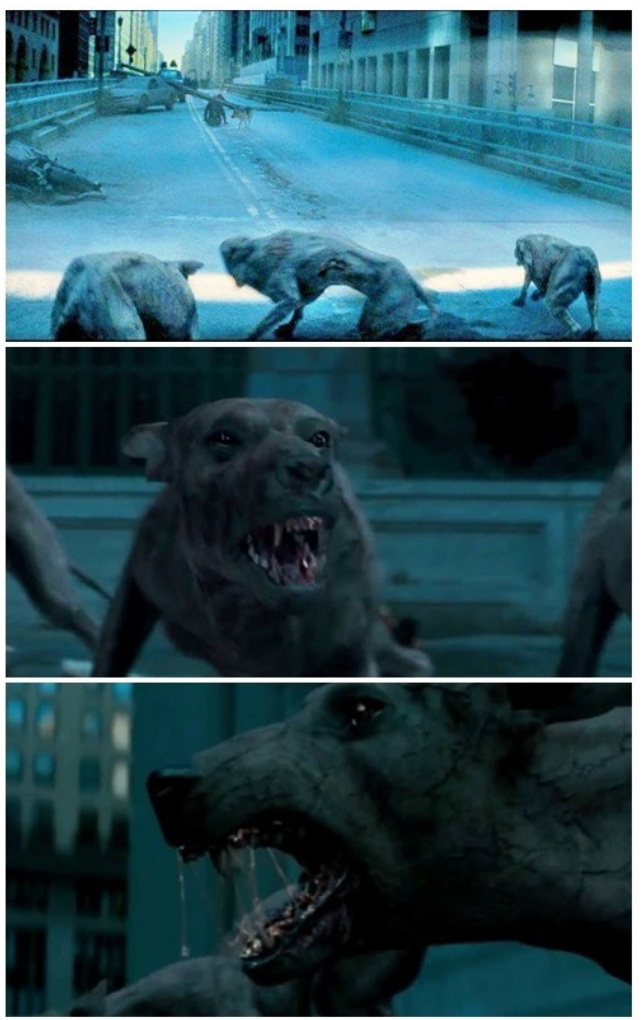

O surto não tem início por vetor animal, mas bichos infectados podem contaminar outros seres - como mostra a cena em que três cães vampíricos atacam o pastor alemão de Neville. Mortos-vivos enraivecidos, esse temível trio incontrolável é nitidamente motivado por Cérbero, o cachorro de três cabeças que guarda os portões do Hades, o reino dos mortos. Conforme Brandão (1986, p. 243), o cão mítico do Hades, própria imagem do cão infernal, evidencia "[...] o terror da morte; simboliza os próprios Infernos e o inferno interior de cada um". Durand (2012, p. 86) complementa que o cachorro, assim como seu ancestral canídeo, o lobo mortífero e devorador, se aproxima simbolicamente da passagem do tempo, da finitude, das trevas e dos corpos celestes noturnos, sendo "[...] igualmente símbolo da morte" e da "[...] lua negra, a lua devorada", ou seja, a lua em eclipse. Portanto, lobo e cão que uivam à lua também uivam à morte. 
O simbolismo obscuro e mortífero ligado ao lobo e ao cão, que aterroriza os humanos há gerações, também provoca emanações simbólicas infernais em $R E C$. No longa que mistura ciência, religião e possessão demoníaca em uma trama zumbi confinada em um prédio, o cãozinho de uma menina acaba sendo infectado pela paciente zero, moradora do sótão. O animal, que é apenas citado nas cenas, pois já está internado em estado grave em uma veterinária, amplia o surto contaminando a criança e dois idosos. O ápice do contágio se dá em uma noite muito escura em Barcelona. Dentro do prédio, uma inesperada falta de energia deixa os personagens nas trevas - e mais suscetíveis ao ataque de zumbis e à morte por devoração de bocas dentadas já não humanas. Na escuridão macabra de REC a lua não aparece. Foi simbolicamente devorada pelo cãozinho infernal e por zumbis famintos. Já o prédio que é palco do surto mortal torna-se mesmo uma casa dos mortos, domínio de Hades - ou o Hades na Terra.

Os astros e os movimentos cósmicos relativos à passagem do tempo que consome a vida, assim como a imagem arquetípica da devoração, motivadora da imagem simbólica da boca dentada, são conteúdos imaginários que constelam não apenas com as imagens do cão e do lobo, mas também com o simbolismo do leão. O grande felino aparece tanto em Os 12 macacos quanto em Eu sou a lenda. Em posição soberana de domínio, no primeiro filme, ou durante a caça, no segundo, o leão exibe sua terrível boca ameaçando os protagonistas com seu rugido incomparável. Motivo de pânico entre humanos, grandes felinos como o leão, o tigre e a pantera são devoradores de carne, incluindo a humana, porém são simbolizados, sobretudo em culturas antigas, como comedores do sol e da lua. Em mitos mouros, hindus, croatas e ameríndios, felinos simbolizam tanto o poder divino quanto essa capacidade cósmica devoradora, sendo explicação mítica e mágica para eclipses. Durand (2012, p. 87) observa a recorrência do leão e de seus semelhantes em mitos e lendas, concluindo que o felino é "[...] ligado no zodíaco ao sol que queima e à morte, passa por devorar os filhos (...), e entra na composição da famosa imagem da Esfinge". 
O leão é, portanto, também um animal terrível, aparentado ao Crono ${ }^{23}$ astral. Krappe ${ }^{24}$ mostra-nos numerosas lendas (...) nas quais o sol mais ou menos leonino devora a lua. (...) Os eclipses são (...) universalmente considerados destruições, por mordedura, do astro solar ou lunar. Os mexicanos pré-colombianos empregavam a expressão (...) "devoração do sol e da lua". Encontramos as mesmas crenças entre os caribes e os mouros, e entre os índios tupi é o jaguar o animal devorador. Entre os nagas de Assam é um tigre (...) que se entrega a esse funesto festim (DURAND, 2012, p. 87).

O autor reforça o alinhamento entre leão e sol apontando para a ambivalência do felino-astro devorador-devorado (sol leonino consumido em eclipse) vir a cristalizar-se na agressão bestial comum ao leão selvagem e à passagem temporal. Assim, a imagem da devoração e o leão devorador constelam na simbolização mítica da consumação pelo tempo.

O sol é ao mesmo tempo leão e devorado pelo leão. (...) Este animal que devora o sol e esse sol devorador e tenebroso parece-nos ser um parente próximo do Crono grego, símbolo da instabilidade do tempo destruidor (DURAND, 2012, p. 87).

Figura 5 - Cena de Os 12 macacos (1995, foto de divulgação).

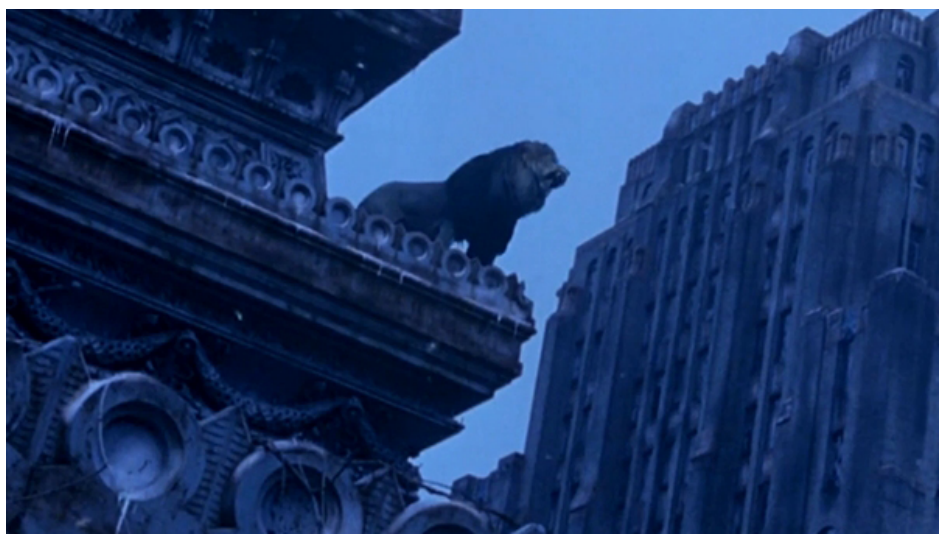

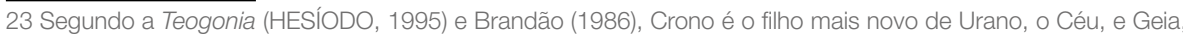
a Terra, sendo parte da primeira geração divina, anterior aos Olimpianos. Foi o único dos irmãos que ajudou a mãe a vingar-se do pai, que expulsava seus filhos do seu reino celeste. Após cortar os testículos de Urano com uma foice, Crono tomou seu lugar no céu. Porém, informado por Urano e Geia que seria destronado por um de seus filhos, Crono passou a devorá-los à medida que nasciam. Assim, gerou e devorou sucessivamente Héstia, Deméter, Hera, Hades e Poseidon. Grávida de Zeus, Geia foge para Creta, onde dá à luz. Rebelado, Zeus derrota Crono, que devolve todos os filhos que havia devorado. Zeus encarcera Crono e os outros Titãs no Tártaro, passando a reinar no Olimpo.

24 Trata-se do folclorista Alexander Haggerty Krappe, autor de La gènese des mythes (1952). 
A imagem simbólica do leão, devorador cósmico, associa-se à imagem mítica de Crono, deus devorador dos filhos e simbolizador do tempo que consome o indivíduo engolindo-o, jogando-o nas trevas vertiginosas da morte. No longa Os 12 macacos, o leão solar dentado ruge no alto de um prédio em um dia escuro de inverno, sugerindo que o tempo do protagonista na superfície contaminada está no fim. É hora de o personagem voltar à jaula subterrânea onde cumpre pena, sim, como bem demonstra a sequência fílmica. Porém, a imagem simbólica do leão inspira na cena (e no filme como um todo) o sentido da morte que se aproxima do personagem juntamente com o tempo devorador que passa sem controle - algo igualmente confirmado ao fim do longa. Já em Eu sou a lenda, o ataque de uma leoa a um cervo ${ }^{25}$, que interrompe a caça de Neville por carne fresca, se dá justamente ao pôr do sol, momento limite para o cientista voltar para casa antes que o cair da noite signifique sua própria queda nas trevas dentadas dos vampiros de Nova York.

\section{Considerações finais}

O cinema pensa o indivíduo, o mundo, a vida e a morte a partir de sua linguagem. Porém, se realizadores abordam temas variados em suas obras para contemplar e problematizar a existência é porque a fantástica imaginação humana responde à força semântica do imaginário antropológico. Sistema organizador de imagens, mitos, metáforas e sentidos, o imaginário energiza a simbolização que inspira o sagrado, a cultura, as artes, as mídias e, claro, o cinema. Portanto, os conteúdos do imaginário que afloram no cotidiano e no processo criativo acabam dinamizando filmes.

Neste artigo, ao destacarmos o teor imaginário de longas-metragens sobre surtos, epidemias e pandemias que apresentam animais como vetores de vírus, bactérias ou parasitas, procuramos evidenciar a carga simbólica que reage à aflição provocada pela passagem do tempo e pela certeza da morte em decorrência de nossas antigas experiências com determinadas espécies da fauna. Assim, buscamos

$25 \bigcirc$ cervo simboliza a prudência, segundo o naturalista romano Plínio. Media céu e terra nas tradições celtas e germânicas. Simboliza fecundidade, virtuosidade, pureza, vitalidade e ressurreição, conforme o Bestiarie du Moyen Âge (TESNIĖRE; DELCOURT, 2020). 
compreender o que os mistérios e os sentidos mais profundos advindos do imaginário querem dizer quando inspiram as obras cinematográficas aqui estudadas. Para isso, sublinhamos o que há de mais universal nas histórias contadas pelos dez filmes do corpus: as imagens arquetípicas, os simbolismos e os resquícios míticos que integram certo imaginário do pandêmico dinamizador das narrativas audiovisuais.

Nesses filmes, percebemos a presença da imagem simbólica do inimigo invisível ligada ao medo da ameaça microbiológica, imperceptível ao sujeito, mas evidente nos contágios, doenças e mortes provocadas por agentes patogênicos. O receio do inimigo invisível é onipresente, pois o perigo microscópico é silencioso e furtivo. A ameaça não visível alinha todas as tramas e se explica simbolicamente pela ligação mítica direta que há entre a morte, a invisibilidade e o apagamento da existência dos mortais nas sombras do Hades.

No bestiário deste imaginário do pandêmico, as imagens simbólicas ligadas a certas espécies se destacam. É caso de animais alados como aves e morcegos ou de animais terrestres, especialmente ratos, macacos, cães e o leão. No caso dos três últimos, há uma convergência bastante evidente entre eles e a imagem arquetípica da devoração e a imagem simbólica da boca dentada. Além disso, o leão pode simbolizar a consumação mítica da vida humana pelo tempo, jogando o sujeito imaginante em um abismo de enfermidades incapacitantes, trevas e morte.

Como ressaltamos, essas imagens simbólicas podem despertar sentidos de valorizações positivas e negativas no amplo imaginário humano. Entretanto, no imaginário do pandêmico estimulador dos longas-metragens deste corpus são os sentidos nefastos e terríveis que se sobressaem, lançando um semantismo de sombras, medo, dor e desespero sobre as narrativas audiovisuais.

Nossa interpretação dos filmes pela perspectiva do imaginário fez emanar antigas imagens, simbolismos e fragmentos míticos que ainda circulam na contemporaneidade inspirando as pessoas, a cultura, as artes e as mídias. Esses conteúdos simbólicos imprimem sentidos figurados aos longas-metragens, pois a irradiação semântica do imaginário sobre a produção cinematográfica é incessante. 


\section{REFERÊNCIAS}

AUMONT, Jacques. A imagem. São Paulo: Papirus, 2011.

AUMONT, Jacques; MARIE, Michel. A análise do filme. Lisboa: Edições Texto\&Grafia, 2013.

BACHELARD, Gaston. L'air et les songes : essai sur l'imagination du mouvement. Paris: Librairie José Corti, 1990.

BARROS, Eduardo Portanova; CARLI, Anelise Angeli de; FANTINEL, Danilo. Diferenças imagéticas: considerações sobre a técnica e o símbolo no contexto comunicacional. Rumores, São Paulo, v. 10, n. 19, p. 209-226, jan. 2016. Disponível em: http://www.revistas.usp.br/Rumores/article/ view/103232/115195. Acesso em: 10 ago. 2020.

BBC News Brasil. Coronavírus: animais ganham as ruas durante quarentena humana. 2020. Disponível em: https://youtu.be/VyJzjo5fsrQ. Acesso em: 25 ago. 2020.

BECHARA, Márcia. Quando os animais invadem os espaços urbanos no meio da pandemia de Covid-19. 2020. Radio France Internationale. Disponível em: https://rfi.my/5kDx. Acesso em: 25 ago. 2020.

BRANDÃO, Junito de Souza. Mitologia grega: volume 1. Petrópolis: Vozes, 1986.

CONTRERA, Malena Segura. Mediosfera: meios, imaginário e desencantamento do mundo. Porto Alegre: Imaginalis, 2017.

DOMINGUEZ, Nuño. Cientistas captam uma enorme onda gravitacional que não deveria existir. 2020. El País Brasil. Disponível em: https://brasil.elpais.com/ciencia/2020-09-02/cientistas-captam-uma-enorme-onda-gravitacional-que-nao-deveria-existir.html. Acesso em: 25 ago. 2020.

DURAND, Gillbert. A imaginação simbólica. Lisboa: Edições 70, 2000.

As estruturas antropológicas do imaginário: introdução à arquetipologia geral. São Paulo: Martins Fontes, 2012.

ELIADE, Mircea. Imagens e símbolos: ensaio sobre o simbolismo mágico-religioso. São Paulo: Martins Fontes, 2002.

Mito e realidade. São Paulo: Perspectiva, 2016.

FANTINEL, Danilo. Caos, escatologia e morte: sintomas de um imaginário do pandêmico no cinema. Revista Zanzalá, Campinas, v. 5, p. 27-49, 2021.

- Mitocrítica fílmica: percursos para a pesquisa e a interpretação de filmes pela heurística do imaginário. In: LEPRI, Adil Giovanni; SCAVONE, Joice (org.). Pontes para o audiovisual: teorias e métodos. Rio de Janeiro: PPGCine/UFF e Nau Editora, 2020, v. 1, p. 37-54.

FLUSSER, Vilém. A filosofia da caixa preta: ensaios para uma futura filosofia da fotografia. São Paulo: Annablume, 2011.

HESÍODO. Teogonia: a origem dos deuses. São Paulo: lluminuras, 1995.

HUIZINGA, Johan. O Outono da Idade Média. São Paulo: Cosac Naify, 2010. 
KRAPPE, Alexander Haggerty. La genèse des mythes. Paris: Payot, 1952.

LANZONI, Will; ALMOND, Kyle. With cities on lockdown, animals are finding more room to roam. 2020. CNN. Disponível em: https://edition.cnn.com/2020/05/01/world/gallery/animals-coronavirus-trnd/index.html. Acesso em: 25 ago. 2020.

MACHLINE, Vera. O que foi a peste negra e quanta gente ela matou?. 2011. Superinteressante. Disponível em: https://super.abril.com.br/mundo-estranho/o-que-foi-a-peste-negra-e-quanta-gente-ela-matou/. Acesso em: 30 ago. 2020.

MARQUES, José Geraldo W. Pássaro é bom para se pensar: simbolismo ascensional em uma Etnoecologia do Imaginário. Revista Incelências, CESMAC, Maceió, v. 1, n. 1, 2010, p. 02-17. Disponivel em: https://revistas.cesmac.edu.br/index.php/incelencias/article/view/98. Acesso em: 19 ago. 2020.

PANCINI, Laura. Não há provas de que Wuhan foi epicentro da pandemia, diz OMS. 2021. Exame. Disponível em: https://exame.com/ciencia/nao-ha-provas-de-que-wuhan-foi-epicentro-da-pandemia-diz-oms/. Acesso em: 23 fev. 2021.

SCHILLING, Voltaire. Peste negra: A Grande Peste - Primeira Fase. 2020. Terra. Disponível em: https://www.terra.com.br/noticias/educacao/historia/peste-negra-a-grande-peste-primeira-fase,923b546f2350802e48680a644b246d62aaa9eg9b.html. Acesso em: 30 ago. 2020.

TESNIÈRE, Marie-Hélène; DELCOURT, Thierry. Bestiarie du Moyen Âge. Paris: Somogy, 2004. Disponível em: http://expositions.bnf.fr/bestiaire/index.htm. Acesso em: 15 jul. 2020.

UFSC. Partículas do novo coronavírus são descobertas em amostra do esgoto de Florianópolis de novembro de 2019. 2020. Disponível em: https://noticias.ufsc.br/2020/07/particulas-do-novo-coronavirus-sao-descobertas-em-amostra-do-esgoto-de-novembro-de-2019/. Acesso em: 27 ago. 2020.

VERNANT, Jean-Pierre. Mito e pensamento entre os gregos. Rio de Janeiro: Paz e Terra, 1990.

WORLD HEALTH ORGANIZATION. Origin of SARS-CoV-2. 2020. Disponível em: https://apps. who.int/iris/bitstream/handle/10665/332197/WHO-2019-nCoV-FAQ-Virus_origin-2020.1-eng.pdf. Acesso em: 25 ago. 2020.

\section{FILMOGRAFIA}

A gripe (Flu, dir. Sung-su Kim, Coreia do Sul, 2013).

Contágio (Contagion, dir. Steven Soderberg, Emirados Árabes Unidos e EUA, 2011).

Epidemia (Outbreak, dir. Wolfgang Petersen, EUA, 1995).

Eu sou a lenda (I am legend, dir. Francis Lawrence, EUA, 2007).

Extermínio (28 days later, dir. Danny Boyle, Reino Unido e Espanha, 2002).

O sétimo selo (Det sjunde inseglet, dir. Ingmar Bergman, Suécia, 1957). 
Os 12 macacos (Twelve Monkeys, dir. Terry Gilliam, 1995).

Pânico nas ruas (Panic in the Streets, dir.Elia Kazan, EUA, 1950).

REC (REC, dir. Jaume Balagueró e Paco Plaza, Espanha, 2007).

The bay (The bay, dir. Barry Levinson, EUA, 2012).

Recebido em: 13/09/20

Aprovado em: 10/03/21 


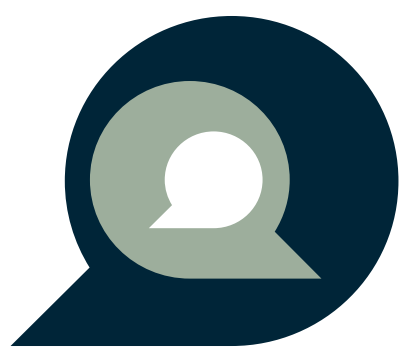




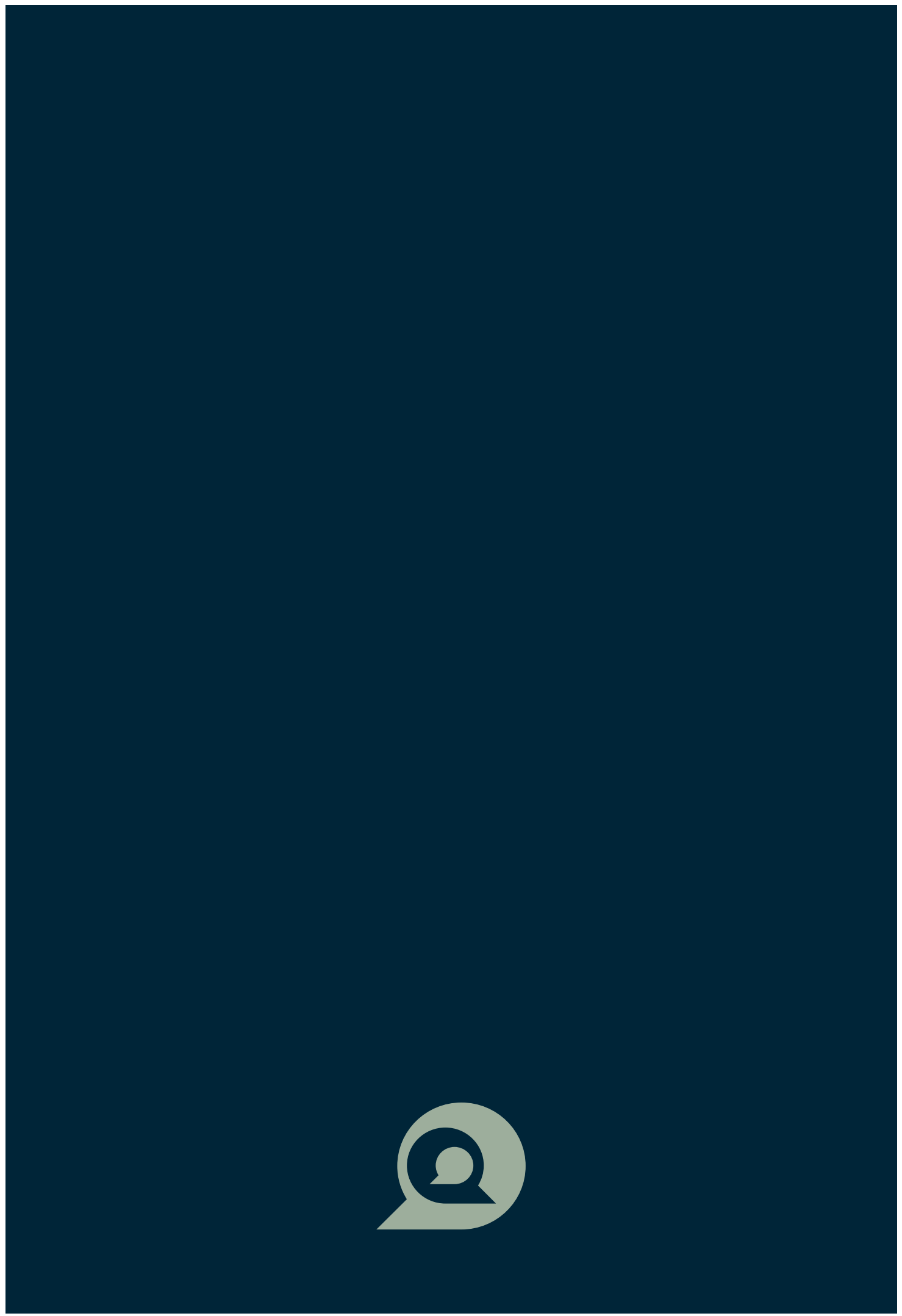

